\title{
Urethritis Glandularis
}

National Cancer Institute

\section{Source}

National Cancer Institute. Urethritis Glandularis. NCI Thesaurus. Code C96226.

A reactive inflammatory disorder affecting the urethra. It is characterized by the development of small cysts in the urethral wall. The cysts are lined by metaplastic glandular cells. 